\title{
ІНТЕРАКТИВНА ВІЗУАЛІЗАЦІЯ ЯК СПОСІБ ПРЕДСТАВЛЕННЯ ВЕЛИКИХ ОБСЯГІВ ДАНИХ У МЕДІА (НА ПРИКЛАДІ ВИДАННЯ «THЕ GUARDIAN»)
}

\author{
Анна Ліченко \\ Міжнародний економіко-гуманітарний університет \\ імені академіка Степана Дем'янчука, \\ вул. акад. С. Дем'янчука, 4, 33027, Рівне, Украӥна \\ e-mail:pocket.pin@gmail.com \\ https://orcid.org/0000-0002-3327-2323
}

У статті виокремлено й охарактеризовано основні типи інтерактивних візуалізацій даних у медіа. Узагальнено базові принципи візуалізації даних. Окреслено вплив інтерактивності на сприйняття контенту медіа-аудиторією, а також вплив візуального образу на процес інтерпретації даних реципієнтами.

Ключові слова: дані, візуалізація даних, інтерактивна візуалізація, журналістика даних, візуальні комунікації.

Для редакцій мас-медіа питання пошуку найбільш ефективних способів донесення інформації до аудиторії завжди було і є одним із найбільш актуальних. Також для засобів масової інформації вкрай важливо, щоб реципієнт не лише отримував повідомлення, а й міг його правильно інтерпретувати. Проте зі стрімким розвитком цифрових технологій перед редакторами поставало все більше й більше нових викликів, пов’язаних зі сприйняттям контенту. Серед них інформаційна перевантаженість індивідуумів, що спричиняє заголовкове читання й тяжіння до малих жанрових форм. Сьогодні медіа вже навчилися боротися за трафік і кліки (від англ. «click» - клацання); вони легко адаптують контент до перегляду на різних пристроях та онлайн платформах. Журналістика стала кросмедійною, одну й ту ж новину подають у формі твіта, замітки, подкасту, відео тощо, але нова проблема - це боротьба за час, який аудиторія приділяє контенту. Пересічний читач у середньому витрачає на перегляд веб-сторінки 15 секунд [1], зважаючи на це, медіа все частіше вдаються до візуалізації інформації, адже графічні образи допомагають реципієнту швидше й ефективніше сприймати великі обсяги даних. Наочність сприяє активізації асоціативного сприйняття й кращому запам'ятовуванню, а інтерактивність передбачає безпосередню участь користувача.

У звіті Digital News Report 2017, опублікованому Reuters Institute, зазначається, що 29\% респондентів (онлайн опитування проводилось у 36 країнах, у кожній з яких

(C) Ліченко А., 2019

Наукове рецензування і рекомендація до друку - проф. Е. Д. Циховська. 
вибірка склала близько 2 тис. осіб - авт. прим.) відповіли, що часто або інколи утримуються від читання новин, здебільшого причинами є негативний вплив на настрій (48\%) та сумніви щодо достовірності (37\%) [2, с. 41]. 3 цього можемо виокремити ще два важливі виклики для медіа - емотивність як фактор комунікації та втрата довіри аудиторії. У контексті вище окреслених проблем розглянемо специфіку використання в мас-медіа інтерактивної візуалізації як способу ефективної репрезентації великих обсягів даних.

Вивченню візуальних комунікацій присвячено чимало досліджень як вітчизняних, так і зарубіжних науковців, зокрема В. Шевченко, О. Ситник, Г. Цуканової, О. Гресько, С. Сімакової, Р. Вільямса, Дж. Ньютон, П. Лестера, Н. Дуарте та ін. Принципи, методи та практичні аспекти візуалізації даних окреслено в працях: «Data Points: Visualization That Means Something» N. Yau; «Handbook of Data Visualization» (за ред. Chun-houh Chen, Wolfgang Karl Härdle, Antony Unwin); «Beautiful Visualization: Looking at Data through the Eyes of Experts» J. Steele, N. Iliinsky; «Narrative Visualization: Telling Stories with Data» E. Segel, J. Heer; «The Visual Display of Quantitative Information» E. Tufte та ін. Натомість у вітчизняній науці про соціальні комунікації питання застосування інтерактивних візуалізацій для репрезентації великих обсягів даних практично не розглядалося, тому дослідження вказаної проблеми є актуальним.

Mета статmi - виокремити та охарактеризувати функціональні особливості інтерактивної візуалізації як способу представлення великих обсягів даних у медіа. Мета дослідження передбачає розв'язання ключових завдань:

- дати визначення поняттям «візуалізація даних», «інтерактивна візуалізація»;

- охарактеризувати основні типи інтерактивних візуалізацій даних у сучасних медіа;

- з'ясувати значення інтерактивного компоненту в системі взаємодії «аудиторія-контент».

У світовій медійній практиці опрацювання й репрезентація великих обсягів даних уже не є новим чи унікальним явищем, дедалі більше редакцій працюють у галузі data-журналістики. Дослідження Google News Lab i PolicyViz, проведене в 2017 році, показує, що 42\% опитаних журналістів засвідчили, що регулярно використовують дані для того, щоб розповідати історії; а 51\% новинних організацій мають у своєму штаті журналіста, що спеціалізується на роботі $з$ даними [3, с. 3]. Робота 3 даними зазвичай передбачає декілька етапів, щонайменше - це збір даних, їх аналіз та візуалізація. У нашому дослідженні ми розглядатимемо останній етап - візуалізацію, адже саме вона є кінцевим результатом, який бачить аудиторія того чи іншого медіа. Спочатку варто з’ясувати значення поняття «візуалізація даних».

Німецький спеціаліст із візуалізації даних і один із співавторів відомої праці «Журналістика даних: Посібник» Грегор Айш зазначає: «Дані самі по собі - як послідовність бітів та байтів, що зберігається у файлі на жорсткому диску комп'ютера - є невидимими. Щоб побачити їх та зрозуміти їхнє значення, нам потрібно візуалізувати ці дані. У цій главі я маю намір використовувати ширше визначення терміну «візуалізація», яке включає навіть просте текстове представлення даних. Наприклад, елементарне завантаження бази даних у програму електронних таблиць вже можна розглядати як візуалізацію даних» [4]. 3 цього розуміємо, що візуалізацію даних можна розглядати у ширшому та вужчому контексті. Ширше тлумачення передбачає, що візуалізація даних - це будь-яке наочне представлення даних (текстове, 
табличне, графічне тощо). Натомість у вужчому контексті візуалізацію даних тлумачать як графічне (статичне або інтерактивне) представлення даних, метою якого $є$ донести до аудиторії значний обсяг інформації в легкій для сприйняття, зрозумілій і лаконічній формі. У нашому дослідженні ми використовуємо вужче тлумачення.

Основне завдання візуалізації даних у мас-медіа - інформувати, за допомогою чисел (кількісної інформації) та графічних образів автор розкриває перед читачем певну цілісну історію; показує раніше небачені взаємозв'язки, кореляції, трансформації, пояснює важливі явища, причини та наслідки тощо. Автор книги «Тһе Functional Art» («Функціональне мистецтво») Альберто Каїро зауважує: «Перша і головна мета будь-якої графіки чи візуалізації - бути інструментом для ваших очей і мозку, що дозволить сприймати те, що знаходиться поза межами їхньої природної досяжності» [5].

Для того, щоб візуалізація була максимально читабельною варто дотримуватись базових принципів візуалізації даних:

- дані повинні бути достовірними, добре структурованими та повними, не варто візуалізувати набір даних, що містить багато пропусків;

- тип візуалізації потрібно вибирати залежно від типу даних та мети (порівняння, показ змін у часі, руху і т.д.);

- візуалізація повинна доносити головні тези, проте не варто обмежуватись виключно представленням числових даних, потрібно розкривати контекст;

- візуалізація повинна містити усі необхідні структурні елементи: заголовок, підзаголовок, вказівку на джерело даних, легенду, назви осей тощо;

- складні для сприйняття візуалізації краще «розбивати» на декілька окремих зображень;

- обирати зрозумілий формат чисел, логічно впорядковувати дані;

- не варто перенавантажувати графік зайвими графічними елементами, які не мають змістового значення, краще надавати перевагу простому дизайну, традиційним поєднанням кольорів тощо.

Інтерактивна візуалізація даних - це різновид графічного представлення даних, що дозволяє користувачу інтерпретувати та аналізувати дані, взаємодіючи 3 ними. Інтерактивність може застосовуватись на рівні зміни кольору, розміру, форми, руху візуальних об'єктів тощо. Розглянемо це на декількох прикладах візуалізацій видання «The Guardian»:

1) зміна розміру графічного об'єкта. У матеріалі «Bezos’s empire: how Amazon became the world's most valuable retailer» («Імперія Безоса: як Аmazon став найдорожчим у світі роздрібним продавцем») [6] за допомогою візуалізації показано, як зростав річний дохід компанії Amazon 31996 року до 2017. Дохід компанії закодовано у формі кола, яке збільшується, коли користувач прокручує сторінку (див. рис. 1).

2) зміна кольору (інтенсивності кольору) графічного об’єкта. У матеріалі «Revealed: one in four Europeans vote populist» («Виявлено: кожен четвертий європеєць голосує за популіста») [7] за допомогою зміни кольору показано, в яких державах найактивніше голосують за популістів, а також трансформацію в часовому вимірі 3 1998 року до 2018. Розшифрувати значення кольору можна за допомогою шкали, що показує відсоток голосів від 0 до 40 (див. рис. 2).

3) рух одного чи декількох об’єктів. У матеріалі «Deadly weather: the human cost of 2018's climate disasters - visual guide» («Смертельна погода: людські втрати від клі- 


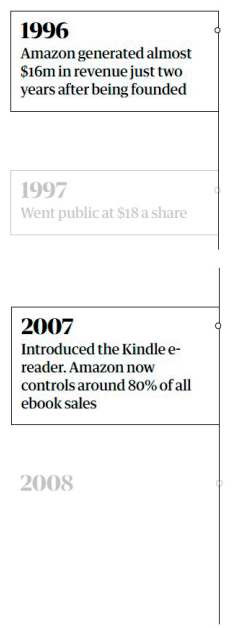

$\$ 15.7 \mathrm{~m}$

\section{- $\quad \mathbf{5 1 5 . 7 m}$}

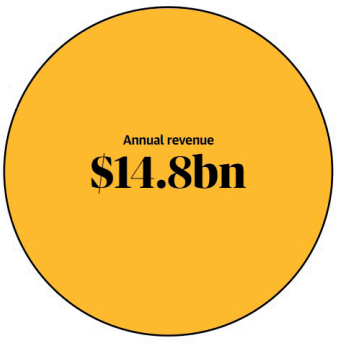

Рис. 1. Приклад інтерактивної візуалізації зі зміною розміру об’єкта [6].

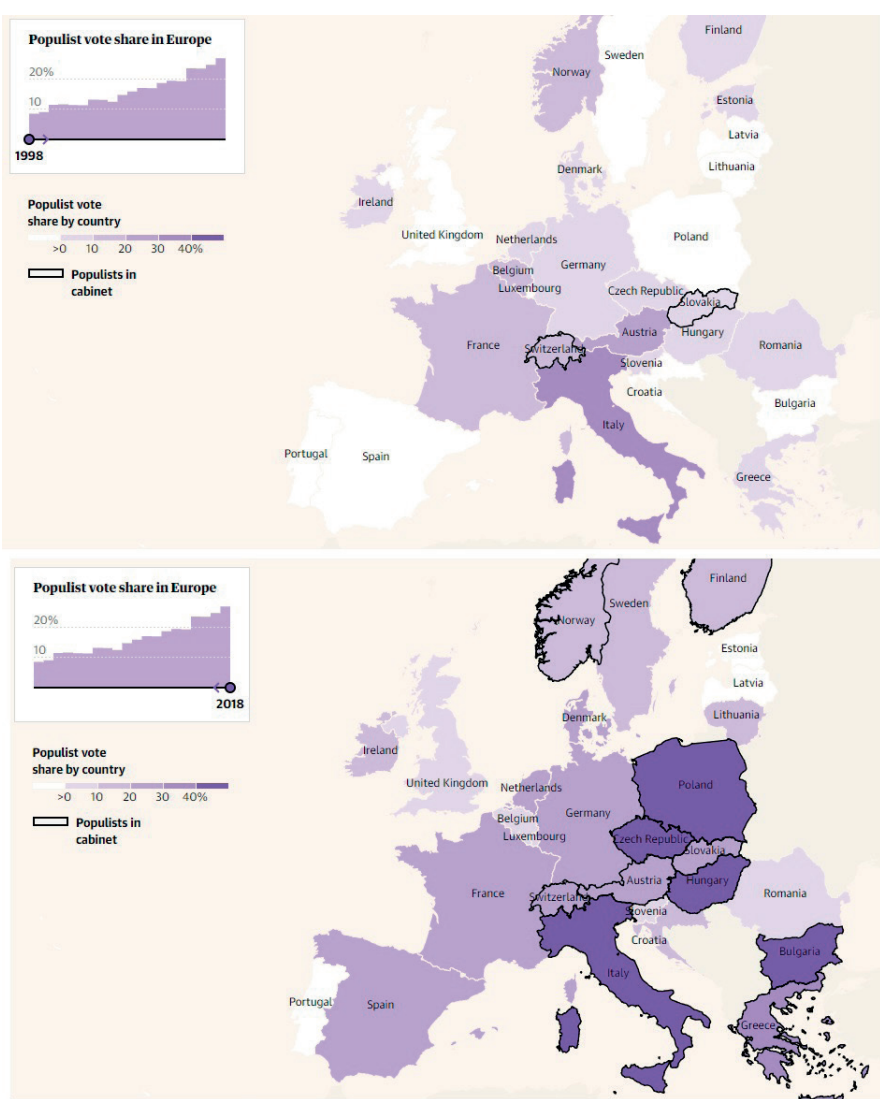

Рuc. 2. Приклад інтерактивної візуалізації зі зміною кольору об'єкта [7]. 


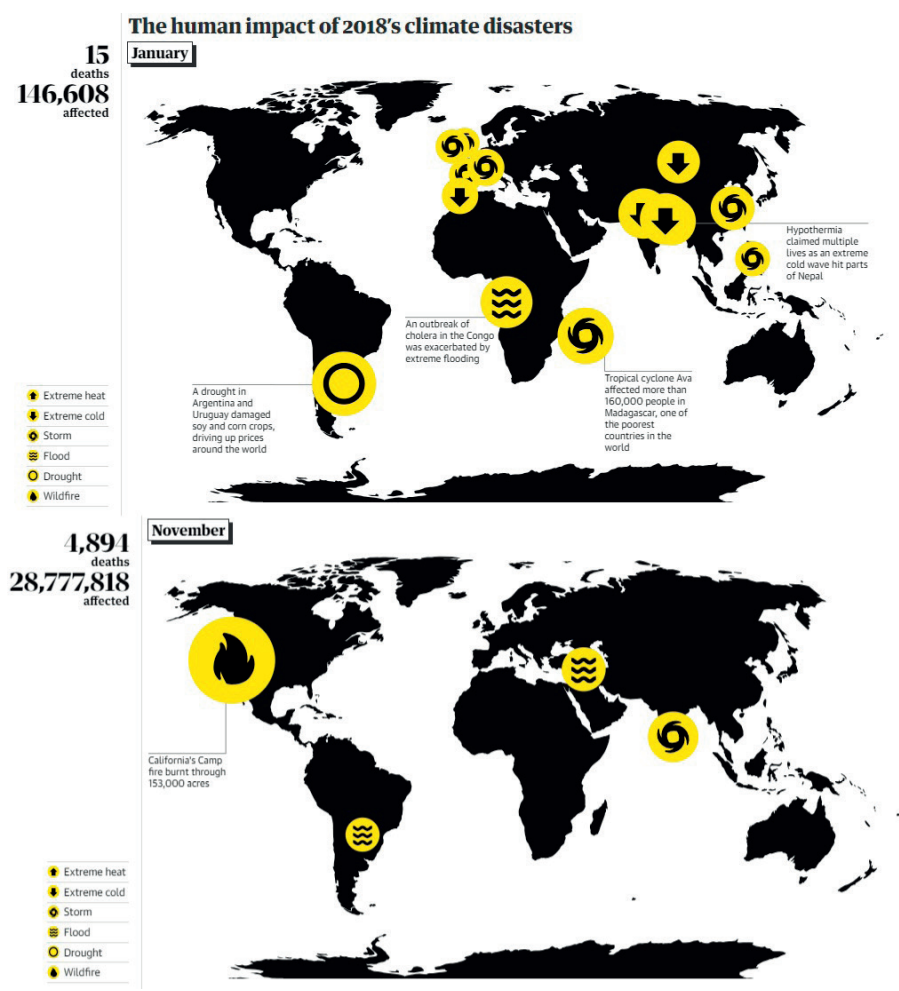

Рис. 3. Приклад інтерактивної візуалізації з рухом об’єктів [8].

матичних катастроф 2018 року: візуальний довідник») [8] представлено дані з ЕМDAT: База даних надзвичайних подій, Université catholique de Louvain (UCL), Центр досліджень епідеміології катастроф, Debarati Guha-Sapir. Візуалізація показує, в яких регіонах світу протягом року були стихійні лиха, що забрали життя 10 і більше осіб. Дані змінюються залежно від місяця (з січня по листопад). Прокручуючи мапу, користувач бачить переміщення умовних позначок на ній, позначки ідентифікують тип катастрофи, а також з'являється текстова інформація, що доповнює чи роз'яснює дані (див. рис. 3).

Також інтерактивність часто застосовується задля ідентифікації графічних елементів, наводячи курсор на певний елемент зображення, графіка чи мапи, користувач бачить мітку, що ідентифікує (пояснюе) елемент ділянки (числове значення, текстове пояснення тощо). Саме ідентифікація є одним із найпростіших й найпоширеніших елементів інтерактивних візуалізацій. Наприклад, такий різновид інтерактивності використаний у візуалізації «European elections: UK results» («Європейські вибори: результати Великобританії») [9], зокрема на мапі можна ідентифікувати регіон і побачити результати голосування.

Ще одним різновидом інтерактивної візуалізації даних є візуалізація, що передбачає кастомізацію (у нашому контексті - це вибір і перегляд користувачем окремого сегменту даних, фільтрація даних за обраними критеріями тощо). Прикладом може бути візуалізація «Which cities are liveable without air conditioning - and for how 
much longer?» («Які міста можуть жити без кондиціонування повітря - і як довго?») [10], читач може обрати з переліку запропонованих міст світу ті, які його цікавлять, і переглянути дані про них. Такий вибір спонукає аудиторію до активної взаємодії 3 контентом, а також це частково вирішує проблему того, що сучасний читач швидко втрачає інтерес до інформації й залишає веб-сторінку.

Основні типи інтерактивних візуалізацій даних у медіа, на наш погляд, доцільно класифікувати залежно від мети (інтенції) візуалізації: опис, порівняння, показ змін у часі, встановлення причинно-наслідкових зв'язків та ін. Це зумовлено тим, що першочергове значення має все ж таки історія, яку розкривають дані, а графічне представлення $\epsilon$ «зовнішньою оболонкою», що полегшує сприйняття інформації, робить їі читабельною та зрозумілою для аудиторії. Таким чином, залежно від мети візуалізації вирізнятимемо інтерактивні візуалізації, що:

- описують явища, події чи процеси («Deadly weather: the human cost of 2018's climate disasters - visual guide» («Смертельна погода: людські втрати від кліматичних катастроф 2018 року: візуальний довідник») [8]);

- порівнюють дані («Gender pay gap: what we learned and how to fix it» («Гендерний розрив у оплаті праці: що ми дізналися і як його виправити?» [11]);

- показують зв’язки та залежності («Watch how the measles outbreak spreads when kids get vaccinated - and when they don't» («Подивіться, як розповсюджується спалах кору, якщо діти вакциновані та якщо ні» [12]);

- демонструють зміни (трансформації) в часовому вимірі («How death has changed over 100 years in Britain» («Як змінилася смертність у Британії за останні 100 років» [13]).

Ще одним важливим аспектом є інтерпретація даних аудиторією, адже читач повинен не лише побачити яскраву інтерактивну картинку, а й правильно розкодувати зміст, зрозуміти сутність історії. Автор книги «Говори мовою діаграм» Джин Желязни пропонує розрізняти «візуальні концепції» (складаються з абстрактних геометричних форм - стрілок, трикутників і т.д.) і «візуальні метафори» (предмети нашого вжитку - сходи, лабіринти, головоломки і т.д.) [14, ст. 112]. На нашу думку, «візуальними метафорами» можна також вважати впізнавані графічні образи, що активують асоціативне сприйняття й таким чином допомагають реципієнту ефективно інтерпретувати інформацію. Такою «візуальною метафорою» може бути навіть колір, наприклад, візуалізуючи дані про кількість пожеж, доцільно використати червоний або помаранчевий колір, який одразу викликає у свідомості читача стійку асоціацію. Аудиторія найкраще сприймає дані, коли вони подані просто, логічно, супроводжуються необхідними роз'ясненнями, зрозумілою легендою. Водночас фахівці зазначають: «Візуалізація має бути легкою для розуміння з першого погляду, але при цьому досить складною для того, щоб запропонувати щось цікаве людям, які хочуть заглибитися в неї» [4].

Отже, інтерактивна візуалізація - це спосіб представлення даних у графічній формі, легкій та доступній для сприйняття. Візуалізації пояснюють складні явища, залежності та зв’язки, але при цьому аудиторія не потребує значних часових затрат на споживання контенту. Серед функціональних особливостей інтерактивних візуалізацій доречно виокремити: здатні привертати увагу аудиторії, а інтерактивність сприяє тому, що читач безпосередньо взаємодіє з контентом; інтерактивність може передбачати кастомізацію, що допомагає аудиторії фільтрувати, порівнювати, ана- 
лізувати дані; активують наочне та асоціативне сприйняття, що якісно впливає на розуміння та запам'ятовування інформації; наочність є складової емотивного сприйняття; можуть використовуватись у якості аргументативної бази. Подальші дослідження з цієї проблеми будуть спрямовані на більш детальне вивчення впливу графічних образів на процес інтерпретації даних читацькою аудиторією.

\section{REFERENCES}

1. Haile T. What You Think You Know about the Web Is Wrong [Електронний ресурс] / Tony Haile // Time. 2014. - Режим доступу : http://time.com/12933/what-you-thinkyou-know-about-the-web-is-wrong/. Дата звернення : 28.01.2019

2. Reuters Institute Digital News Report 2017 / [N. Newman, R. Fletcher, A. Kalogeropoulos та ін.]. $136 \mathrm{c.}$

3. Rogers S. Data Journalism in 2017: The Current State and Challenges Facing the Field Today / S. Rogers, J. Schwabish, D. Bowers., 2017. 24 c.

4. Журналістика даних: Посібник [Електронний ресурс] / За заг. ред. Джонатана Грея, Ліліани Бонегру, Люсі Чемберс. 2012. - Режим доступу : http://texty.org.ua/ $\mathrm{pg} /$ book/newsmaker/read/40161. Дата звернення : 29.01.2019

5. Cairo A. The Functional Art: An introduction to information graphics and visualization [Електронний pecypc] / Alberto Cairo. 2012. - Режим доступу : http://www. elartefuncional.com/images/Intro chapterl.pdf. Дата звернення : 29.01.2019

6. Holder J. Bezos's empire: how Āmazon became the world's most valuable retailer [Електронний pecypc] / J. Holder, A. Hern // The Guardian. 2018. - Режим доступу : https://www.theguardian.com/technology/ng-interactive/2018/apr/24/bezoss-empirehow-amazon-became-the-worlds-biggest-retailer. Дата звернення : 29.01.2019

7. Revealed: one in four Europeans vote populist [Електронний ресурс] / [P. Lewis, C. Barr, J. Holder та ін.] // The Guardian. 2018. - Режим доступу : https://www. theguardian.com/world/ng-interactive/2018/nov/20/revealed-one-in-four-europeansvote-populist?CMP=share_btn_fb. Дата звернення : 29.01.2019

8. Deadly weather: the human cost of 2018's climate disasters - visual guide [Електронний pecypc] / [D. Levitt, P. Andringa, F. Hulley-Jones та ін.] // The Guardian. 2018. Режим доступу : https://www.theguardian.com/environment/ng-interactive/2018/ dec/21/deadly-weather-the-human-cost-of-2018s-climate-disasters-visual-guide. Дата звернення : 30.01 .2019

9. European elections: UK results [Електронний ресурс] // The Guardian. 2014. - Режим доступу : https://www.theguardian.com/politics/ng-interactive/2014/may/25/europeanelections-uk-results. Дата звернення : 30.01 .2019

10. Gray N. Which cities are liveable without air conditioning - and for how much longer? [Електронний pecypc] / N. Gray, A. Voce // The Guardian. - Режим доступу : https:// www.theguardian.com/cities/ng-interactive/2018/aug/14/which-cities-are-liveablewithout-air-conditioning-and-for-how-much-longer. Дата звернення : 30.01.2019

11. Kommenda N. Gender pay gap: what we learned and how to fix it [Електронний ресурс] / N. Kommenda, C. Barr, J. Holder // The Guardian. 2018. - Режим доступу : https://www.theguardian.com/news/ng-interactive/2018/apr/05/women-are-paid-lessthan-men-heres-how-to-fix-it. Дата звернення : 30.01.2019 
12. Harris R. Watch how the measles outbreak spreads when kids get vaccinated - and when they don’t [Електронний ресурс] / R. Harris, N. Popovich, K. Powell // The Guardian. 2015. - Режим доступу : https://www.theguardian.com/society/ng-interactive/2015/ feb/05/-sp-watch-how-measles-outbreak-spreads-when-kids-get-vaccinated. Дата звернення : 30.01.2019

13. Davis N. How death has changed over 100 years in Britain [Електронний ресурс] / N. Davis, N. Kommenda, C. Barr // The Guardian. 2017. - Режим доступу : https://www. theguardian.com/lifeandstyle/ng-interactive/2017/sep/18/how-death-has-changed-over100-years-in-britain?CMP=share_btn_tw. Дата звернення : 30.01.2019

14. Желязны Д. Говори на языке диаграмм: Пособие по визуальным коммуникациям для руководителей / Джин Желязны. М. : Институт комплексных стратегических исследований, 2004. 220 с.

\title{
INTERACTIVE VISUALIZATION AS A WAY OF REPRESENTING A LARGE AMOUNT OF DATA IN THE MEDIA (ON THE EXAMPLE OF THE GUARDIAN)
}

\author{
Anna Lichenko \\ International Economics and Humanities University \\ Academician Stepan Demyanchuk's Name, \\ acad. S. Demianchuk Str., 4, 33027, Rivne, Ukraine \\ e-mail:pocket.pin@gmail.com \\ https://orcid.org/0000-0002-3327-2323
}

This paper classifies and describes the main types of interactive data visualization in the media. It also provides a brief overview of the basic principles of data visualizations. We have attempted to explain the impact of interactivity on the perception of information by the audience. We defined interactive visualization as a form of graphical representation of data that enables the exploration and interpretation of data via the manipulation of chart images (for example, the color, size, shape, and movement of objects can be changed).

Media audience is much better at understanding data when it is presented graphically rather than numerically. The readership should interpret the data correctly, so journalists need to follow the basic rules of visualization, for example, the visualization must contain all the necessary structural elements: title, subtitle, indication of the data source, legend, names of the axes, etc. The main rule is that data must tell the story. Interactive data visualizations allow the readership to see connections in data, correlations, and changes in time, etc. We propose to classify interactive data visualization depending on the purpose of visualizing. We have made the following conclusions: interactive visualization is one of the most effective ways of representing the data because it helps people quickly examine and understand information; interactivity also helps attract and retain reader attention; interactive functionality helps enhance data analysis; interactive map is one of the most commonly used types of data visualization; data visualization is used as a component of argumentation in analytical articles.

Key words: data, data visualization, interactive visualization, data journalism, visual communications. 